Andres Enriquez ORCID iD: 0000-0002-8146-360X

Adrian Baranchuk ORCID iD: 0000-0002-3042-6569

\title{
Update on Long QT Syndrome
}

${ }^{1}$ Víctor Neira MD, ${ }^{1}$ Andrés Enriquez MD, ${ }^{1}$ Chris Simpson MD, ${ }^{1}$ Adrian Baranchuk MD.

1. Division of Cardiology, Queen’s University, Kingston, Ontario, Canada.

Keywords: Long QT; QT interval; electrocardiography; torsades de pointes

Conflict of interest: None

Funding: None

Corresponding Author:

Dr. Adrian Baranchuk, MD FACC FRCPC FCCS

Professor of Medicine

Division of Cardiology

Cardiac Electrophysiology and Pacing

Queen’s University

76 Stuart Street, Kingston, Ontario K7L 2V7

Phone: 6135496666 ext. 3801

Fax: 6135481387

Email: Adrian.Baranchuk@kingstonhsc.ca

This article has been accepted for publication and undergone full peer review but has not been through the copyediting, typesetting, pagination and proofreading process, which may lead to differences between this version and the Version of Record. Please cite this article as doi: 10.1111/jce.14227.

This article is protected by copyright. All rights reserved. 


\begin{abstract}
Long QT syndrome (LQTS) is an inherited disorder characterized by a prolonged QT interval in the 12-lead electrocardiogram and increased risk of malignant arrhythmias in patients with a structurally normal heart. Since its first description in the 1950s, advances in molecular genetics have greatly improved our understanding of the cause and mechanisms of this disease. Sixteen genes linked to LQTS have been described and genetic testing had become an integral part of the diagnosis and risk stratification. This article provides an updated review of the genetic basis, diagnosis and clinical management of LQTS.
\end{abstract}

\title{
Introduction
}

Long QT syndrome (LQTS) is an inherited cardiac condition characterized by a phenotype of QT prolongation on the electrocardiogram (ECG) and an increased risk of life-threatening ventricular arrhythmias.

LQTS is caused by altered expression or function of repolarizing ionic channels, mainly "loss-of-function" potassium channels mutations or "gain-offunction" sodium or calcium channel mutations that result in reduction of net repolarizing currents. More than 600 mutations have been identified in 16 LQTS genes, however $20 \%$ of LQTS remains genetically elusive (1).

The first descriptions of LQTS identified two patterns of inheritance: the more common autosomal dominant variant (Romano-Ward syndrome) and the rare and severe autosomal recessive variant (Jervell and Lange-Nielsen syndrome), which is accompanied by congenital deafness (2). Description of sudden deaths in children with congenital deafness and prolonged QT intervals emerged in the late 1950s, followed shortly thereafter by reports of families with sudden death and long QT intervals but without deafness (3). However it took another 4 decades to understand the genetic basis of the disease with the description of HERG and SCN5A as the culprit genes for the second and third forms of congenital LQTS $(4,5)$.

LQTS has a prevalence estimated at 1/2000-25000 (6) and is a leading cause of sudden cardiac death in young individuals with structurally normal hearts. Symptomatic patients without treatment have a high mortality rate - up to $21 \%$ within a year of the first episode of syncope (7). However, with proper treatment mortality diminishes to approximately $1 \%$ over a 15 -year follow-up (8).

\section{Methods}

This is a non-systematic review. Article selection was performed by the authors according to their evaluation of the most significant contributions.

This article is protected by copyright. All rights reserved. 


\section{Results and Discussion}

\section{Molecular mechanisms}

In LQTS, prolongation of the ventricular cardiac potential can be caused by genetic defects resulting in decrease of repolarizing potassium currents $\left(I_{\mathrm{Ks}}, I_{\mathrm{Kr}}\right.$, and $\left.I_{\mathrm{K} 1}\right)$ or enhancement of depolarizing sodium and calcium currents $\left(I_{\mathrm{Na}}\right.$ and $\left.I_{\mathrm{Ca}, \mathrm{L}}\right)(9)$.

Molecular and genetic studies in humans have uncovered many of the genes associated with LQTS, providing molecular insights into the pathogenesis of the disease. Three main genes account for approximately $90 \%$ of the patients with genotype-positive and around 75\% of all patient with clinically-diagnosed LQTS (1). LQT1 is caused by loss-of-function mutations in KCNQ1, which encodes the $\alpha$ subunit of the slowly activating potassium channel Kv7.1, leading to reduced $I_{\mathrm{Ks}}$ current. $I_{\mathrm{Ks}}$ and $I_{\mathrm{Kr}}$ are the slow and rapid components of the delayed rectifier IK current, the major determinant of Phase 3 of the cardiac action potential. In physiological conditions, $I_{\mathrm{Ks}}$ is increased by sympathetic stimulation and is essential for QT adaptation during tachycardia. Most cases of the autosomal recessive Jervell and Lange-Nielsen syndrome are caused by homozygous or compound heterozygous mutations in KCNQ1. LQT2 is associated with loss-of-function mutations in KCNH2 ( $h E R G$ ) and a reduced rapidly-activating potassium current $I_{\mathrm{Kr}}$. LQT3 is caused by gain-of-function mutations in $S C N 5 A$ resulting in increased $I_{\mathrm{Na}}$ current during the plateau and late phase of the action potential.

Several other genes, also known as minor LQTS genes, have been identified and collectively account for about 5\% of clinically diagnosed cases of LQTS (Table 1). A reduced $I_{\mathrm{Ks}}$ can also be due to mutations in KCNE1 and KCNE2, which encode potassium channel subunits (LQT5 and LQT6) (10), or AKAP9, which encodes a protein kinase involved in the phosphorylation of KCNQ1 (LQTS11) (11). Other potassium channel-encoding genes linked to LQTS include KCNJ2 and KCNJ5 (LQT7 and LQT13), the first one associated with Andersen-Tawil syndrome (periodic paralysis, dysmorphic features and long QT) $(12,13)$. Mutations in genes encoding the sodium channel regulatory proteins CAV3, SCN4B and SNTA1 (LQT9, LQT10 and LQT12) may produce gain of function in $I_{\mathrm{Na}}$ and a LQT3-like phenotype (14-16). Increased calcium current can be caused by mutations in CACNA1C, which encodes a voltage-gated calcium channel (LQT8) (17) or mutations in genes encoding the ubiquitous calcium-sensing protein calmodulin CALM1, CALM2 and CALM3 (LQT14, LQT15 and LQT16) (18). CACNA1C mutations are associated with Timothy syndrome, an extremely malignant variant characterized by marked QT prolongation, autism and syndactilia, while CALM-mediated LQTS have also poor prognosis, with very long QT intervals and high incidence of ventricular arrhythmias, with mean age at onset of 1.5 years. Finally, ANKB (LQT4) encodes a structural protein (ankyrin-B), which anchors ion channels to specific domains in the plasma membrane (19).

Despite the great advances in understanding the genetic basis of LQTS, the mechanisms resulting in arrhythmia susceptibility are less well understood. The occurrence of early/late afterdepolarizations and increased dispersion of repolarization

This article is protected by copyright. All rights reserved. 
are thought to play a role in arrhythmogenesis (20). In LQTS the decrease in net outward current leads to increased calcium uptake via voltage dependent $\mathrm{Ca}^{2+}$ channels on the myocardial cell membrane. This net increase in inward $\mathrm{Ca}^{2+}$ flow leads to $\mathrm{Ca}^{2+}$ dependent calcium release from the sarcoplasmic reticulum in the submembrane intracellular space which in turn leads to new $\mathrm{Na}^{+}$inward current via $\mathrm{Ca}^{2+}-\mathrm{Na}^{+}$ exchange, triggering afterdepolarization-mediated premature ventricular complexes (PVCs), which act as triggers of the arrhythmia $(21,22)$. In addition, there is evidence that patients with LQTS display regional heterogeneities in repolarization caused by localized prolongation of the action potential duration (21,23). This, in turn, predisposes to functional reentry and represents the substrate for torsades de pointes (TdP), the hallmark arrhythmia of LQTS.

When the onset of TdP is recorded, two modes of initiation can be distinguished: pause-dependent (preceded by a "short-long-short" sequence) or tachycardia-dependent (preceded by an increased sinus rate) (24). Tan et al. demonstrated that pause-dependent onset is genotype-specific, being predominant in LQT2, but rare in LQT1 (25), consistent with a different arrhythmia mechanism in each case. Early afterdepolarization (EAD) is most likely to initiate TdP in LQT2 and LQT3; in these cases a pause leads to increased $\mathrm{Ca}^{2+}$ release from intracellular stores and enhanced $\mathrm{Ca}^{2+}$-dependent transmembrane currents (electrogenic $\mathrm{Na}^{+} / \mathrm{Ca}^{2+}$ exchanger), allowing L-type $\mathrm{Ca}^{+}$channels to reactivate before repolarization is complete, thus generating EAD. On the other side, the relatively fast heart rate preceding TdP in LQT1 suggests that delayed afterdepolarizations (DAD) secondary to intracellular $\mathrm{Ca}^{2+}$ overload may be the predominant mechanism of TdP initiation.

\section{Diagnosis}

The diagnosis of LQTS should be suspected based on the clinical presentation, family history, ECG characteristics and genetic testing.

Patients with LQTS may present with syncope, seizures or cardiac arrest due to TdP. Sudden death can be the first manifestation of the disease, but many individuals will be asymptomatic life-long. The onset of symptoms occurs at a mean age of 12 years old, with an earlier onset usually associated with more severe outcomes. Clinical events may be precipitated by specific triggers, including exercise and particularly swimming in LQT1, emotional stress or sudden loud noises in LQT2 and rest in LQT3 (26). A family history of sudden death in a child or young adult supports the diagnosis of LQTS.

Prolongation of the QT interval on 12-lead ECG (QTc $>460 \mathrm{~ms}$ in women and $>450 \mathrm{~ms}$ in men) is the hallmark of LQTS (see Figure 1) (8). However, this may not always be present; $20-25 \%$ of patients with LQTS confirmed by presence of an LQTS gene mutation may have a normal QT interval on a single ECG (i.e. 37\% of LQT1, $10 \%$ of LQT3, etc) (27). Adequate measurement of the QT interval is important in diagnosing LQTS and two main methods are used. In the tangent method, the end of

This article is protected by copyright. All rights reserved. 
the $\mathrm{T}$ wave is defined as the point where the tangent of the steepest point of the terminal limb of the $\mathrm{T}$ wave intersects with the isoelectric baseline. In the threshold method, the end of the $\mathrm{T}$ wave is defined as the intersection of the terminal limb of the $\mathrm{T}$ wave with the isoelectric baseline. A $\mathrm{U}$ wave is always excluded from QT interval analysis. In a large cohort of genotype-positive LQTS patients, Vink et al. found that both methods have a high diagnostic accuracy, however the cutoff for the tangent method should be shorter (for proposed cut-off values by age and sex see Vink et al) (28). An online probability calculator of LQTS is available as an aid in the interpretation of the QT interval (www.QTcalculator.org).

Other ECG features of LQTS include morphological abnormalities of the T waves (e.g. broad-based in LQT1, notched in LQT2, late-appearing in LQT3) or T wave alternans in polarity or amplitude, which is a sign of electrical instability (Figure 2) (29).

According to HRS/EHRA/APHRS Expert Consensus Statement recommendations, a diagnosis of LQTS is made in the presence of a QTc $\geq 500 \mathrm{~ms}$ in repeated 12-lead ECGs, or in the presence of a QTc between 480-499 ms in a patient with unexplained syncope. In both cases a secondary cause for QT prolongation should be excluded. LQTS is also diagnosed in the presence of an unequivocally pathogenic mutation in one of the LQTS genes or in the presence of an LQTS risk score (a clinical scoring system that combines molecular genetic testing and several clinical and electrocardiographic parameters for a score totaling $\geq 3.5$ in the absence of a secondary cause for QT prolongation (Table 2).

Provocative tests, including epinephrine infusion and exercise stress testing can unmask LQTS in patients with normal QTc at rest. Paradoxical prolongation of the QT interval (> $30 \mathrm{~ms}$ ) during low-dose epinephrine infusion (0.05 microg/kg/min) has a sensitivity of $92 \%$, specificity of $86 \%$, a positive predictive value of $75 \%$ and a negative predictive value of $96 \%$ (30). This means that although a negative test almost certainly rules out LQT1, a positive test carries only a 75\% chance that the individual hosts a LQT1 mutation. The Mayo Clinic group reported an 18\% of "false-positive" responses in gene-negative patients and reported that some of these may result from an interpretation error due to incorporation of the $U$ wave at higher epinephrine doses when the $\mathrm{T}$ and $\mathrm{U}$ waves fuse (30). Regarding treadmill stress testing, an absolute QTc $\geq 460 \mathrm{~ms}$ during the recovery phase or a paradoxical increase in QTc (QTc recovery QTc baseline $\geq 30 \mathrm{~ms}$ ) also distinguishes LQTS patients, particularly LQT1, from controls even when the resting QTc is within normal limits (31). Viskin et al. also proposed a simple maneuver based on the response of the QT interval to the brief heart rate acceleration provoked by standing. In a study that included 68 LQTS patients and 82 controls, heart rate increased in response to standing to a similar extent in both groups. However, the QT interval of controls shortened by $21 \pm 19$ ms whereas the QT interval of LQTS patients increased by $4 \pm 34 \mathrm{~ms}$ (p < 0.001) (32). Subsequent analyses showed that abrupt standing may also expose abnormal $\mathrm{T}$ waves that are valuable for diagnosing LQTS (33) and that QTc prolongation may persist even after the heart rate returns to baseline, a phenomenon that has been termed "QT stunning” (34).

This article is protected by copyright. All rights reserved. 


\section{Genetic testing}

Genetic testing for LQTS or other channelopathies should always be sought based on clinical suspicion rather than ordered indiscriminately, as genetic tests are not deterministic but probabilistic tests. Approximately 4\% of healthy white individuals and $6-8 \%$ of non-white individuals may have variants of uncertain significance in one of the three major LQTS-susceptibility genes (KCNQ1, KCNH2 or SCN5A). In addition, the yield of genetic testing among patients with clinically definite LQTS is approximately 70-75\% (35). Therefore, a negative genetic test cannot exclude unequivocally the diagnosis of LQTS.

According to HRS/EHRA Expert Consensus Statement, genetic testing for LQTS is recommended in patients with a strong clinical suspicion for LQTS based on clinical history, family history, 12-lead ECG and/or provocative testing (27). It is also recommended in asymptomatic patients with QT prolongation in the absence of secondary causes (electrolyte abnormalities, hypertrophy, bundle branch block) on serial 12-lead ECGs defined as QTc > $480 \mathrm{~ms}$ (prepuberty) or > $500 \mathrm{~ms}$ (adults), and it may be considered in asymptomatic patients with idiopathic QTc values $>460 \mathrm{~ms}$ (prepuberty) or $>480 \mathrm{~ms}$ (adults) on serial 12-lead ECGs. Either comprehensive genetic testing for all known LQTS genes or targeted genetic testing for the three mayor LQTS genotypes (KCNQ1, KCNH2 and SCN5A) are acceptable strategies. Finally, mutation-specific testing is recommended for family members and other appropriate relatives subsequently following the identification of the LQTS-causative mutation in an index case.

Risk stratification

Genetic and clinical elements influence risk assessment in individuals with LQTS, with several patterns and groups associated with differential risk.

The risk of cardiac events is significantly higher in patients with LQT2 and LQT3 than patients with LQT1 (27). In particular, two genetic variants of LQTS carry a high risk and respond poorly to therapies: the Jervell and Lange-Nielsen syndrome (36) and the Timothy syndrome (LQTS8) (37). In LQT1, both the transmembrane location of the mutation and their dominant-negative effect are independent risk factors for cardiac events (38), whereas in LQT2 patients, mutations in the pore region are associated with higher risk (39).

High risk is also present whenever QTc > $500 \mathrm{~ms}$ and becomes extremely high risk when QTc > 600 ms. The presence of $\mathrm{T}$ wave alternans is a sign of electrical instability and also identifies patients at particularly high risk of events (Figure 2).

Several studies have demonstrated a modulating effect of gender on the clinical course of the disease. The risk of cardiac events is higher among males during childhood, while females are at higher risk after the age of 15 years. In a series of 647 patients of known genotype, sex had no influence among LQT1 patients, whereas lifethreatening events were higher among LQT2 females than LQT2 males, and higher

This article is protected by copyright. All rights reserved. 
among LQT3 males than LQT3 females (27). Other predictors of high risk include a history of life-threatening arrhythmic events before age 7 (40) and the occurrence of arrhythmic events despite being on full medical therapy (41).

Evaluation of family members

When a causative mutation is identified in a clinically affected index case, mutation-specific genetic testing is recommended in all first-degree relatives, including parents, siblings and offspring (Class I recommendation) (42). Genetic testing in relatives is indicated even in the presence of a negative clinical and ECG phenotype, as a normal QT is not sufficient to rule out LQTS. If the genetic test, history and 12-lead ECG are negative, LQTS is ruled out.

Treatment

Anti-adrenergic therapy: Beta-blockers and sympathetic cardiac denervation

Beta-blockers are first-line medical therapy for the prevention of lifethreatening arrhythmias in LQTS (Figure 3) $(42,43)$. They are recommended in all symptomatic patients (syncope or documented VT/VF) and in asymptomatic patients with a resting QTc greater than 470 ms (Evidence Class I), however their use is also reasonable in asymptomatic patients with a resting QTc less than 470 ms (Evidence Class IIa) (42).

The question whether one beta-blocker is superior to another still remains controversial. In a multicenter study including 382 LQT1/LQT2 patients, propranolol and nadolol were significantly more effective than metoprolol at preventing breakthrough cardiac events (44). Another study including 1530 patients from the Rochester LQTS registry who were prescribed beta-blockers before 40 years of age, suggested that propranolol, nadolol, metoprolol and atenolol seemed to be equally effective reducing the risk of first cardiac event, but nadolol was the only beta-blocker associated with a significant risk reduction in patients with LQT2 (45). Finally, another large study including 1710 patients with LQTS followed up for a median of 7.1 years showed that only nadolol significantly reduced the arrhythmic risk in all genotypes compared with no therapy (46). In specialized centers the most widely used betablockers are propanolol (2-4 mg/kg/day) and nadolol (1-2 mg/kg/day), the second one having the advantage of a longer half-life allowing one daily dosing.

The efficacy of betablockers also depends on the genotype, with studies revealing a reduction of cardiac events > 95\% in LQT1, > 75\% in LQT2 and > 60\% in LQT3 (45,47-49). The evidence demonstrates that beta-blocker therapy is highly effective in LQT1 patients, mortality is $0.5 \%$ and sudden death combined with cardiac arrest reaches $1 \%$. The failure in patients with LQT1 is associated with the use of QTprolonging drugs and when these drugs are avoided the risk reduction of cardiac events is $97 \%(40,50)$. Major events occur in $10-15 \%$ of patients with LQT3 patients despite use of beta-blocker therapy (47).

This article is protected by copyright. All rights reserved. 
Left cardiac sympathetic denervation (LSCD) involves ablation of the lower half of the left stellate ganglion (T1) and thoracic ganglia T2 to T4 of the left sympathetic chain with preservation of the upper half of the stellate ganglion (T1) to avoid iatrogenic Horner's syndrome. It results in a $>90 \%$ reduction of cardiac events and a post-LCSD QTc $<500 \mathrm{~ms}$ predicts low risk $(51,52)$. According to AHA/ACC/HRS Guidelines, LSCD should be considered in high-risk patients with symptomatic LQTS in whom beta-blockers are ineffective or not tolerated and in patients with recurrent appropriate ICD shocks despite maximum tolerated doses of beta-blockers (Class I). It may also be considered in asymptomatic patients a resting QTc > 500 ms while receiving beta-blockers (Class IIb) (42).

Gene-specific therapies

Additional pharmacological strategies have been attempted to counteract the functional consequences of LQTS mutations.

LQT2 patients are more susceptible to arrhythmic events when serum $\mathrm{K}^{+}$levels fall. As such, careful maintenance of adequate serum $\mathrm{K}^{+}$levels is recommended with a combination of diet, oral $\mathrm{K}^{+}$supplements and if necessary use of $\mathrm{K}^{+}$-sparring agents such as spironolactone (53).

The fact that LQT3-causing SCN5A mutations are associated with "gain of function" effect supports an adjuvant role of $\mathrm{Na}^{+}$channel blockers in the management of LQT3 patients. Mexiletine, a class Ib antiarrhythmic agent, blocks the late $\mathrm{Na}^{+}$ current and abbreviates the duration of ventricular repolarization in animal models and LQT3 patients (54-56). In a cohort of 34 LQT3 patients, mexiletine significantly shortened QTc by $63 \pm 6 \mathrm{~ms}$ and reduced the annual rate of arrhythmic events (from $10.3 \%$ to $0.7 \%$; $p=0.0097$ ) (57). The effect of mexiletine is mutation-specific (58) and therefore the efficacy of an acute oral dose should be tested under continuos ECG monitoring before starting this agent. Recently, Bos et al. showed that mexiletine also shortens the QTc in two thirds of patients with LQT2, suggesting a possible added therapeutic efficacy to betablocker therapy (59). There is evidence that other $\mathrm{Na}^{+}$ channel blockers such as ranolazine and flecainide shorten the QTc in LQT3 and they have been used to reduce recurrent arrhythmias in this group $(60,61)$.

Lifestyle Modifications

Lifestyle changes are an integral part of LQTS management. These include avoidance of QT-prolonging drugs (see below) and identification and correction of electrolyte abnormalities caused by diarrhea, vomiting, metabolic conditions or imbalanced diets for weight loss (62). The evidence that grapefruit juice prolongs the QT interval in healthy volunteers and patients with LQTS also suggests a role of "proarrhythmic food" (63).

Regarding sports participation, previous guidelines by the $36^{\text {th }}$ Bethesda Conference recommended that patients with either (1) symptoms, (2) a QTc $>470 \mathrm{~ms}$ (males) or $480 \mathrm{~ms}$ (females), or (3) an ICD not participate in most competitive sports

This article is protected by copyright. All rights reserved. 
(64). However, in a large series of athletes with LQTS who chose to remain competitive despite guidelines, the overall rate of cardiac events was quite small (1 event in 331 athlete-years) (65). Accordingly, a more recent statement from the American Heart Association and American College of Cardiology recommended that in asymptomatic athletes with genotype-positive/phenotype-negative LQTS, participation in all competitive sports is reasonable with appropriate precautionary measures, including avoidance of QT-prolonging drugs, electrolyte/hydration replacement, avoidance of hyperthermia and acquisition of a personal automatic external defibrillator. In addition, athletes with either symptomatic LQTS or electrocardiographically manifest LQTS (QTc $>470 \mathrm{~ms}$ in males or $>480 \mathrm{~ms}$ in females) could participate in competitive sports (except competitive swimming in symptomatic LQT1) after institution of treatment and assuming the athlete has been asymptomatic for at least 3 months. The statement also recommends a comprehensive evaluation by a heart rhythm specialist or genetic cardiologist in all athletes with a suspected or diagnosed cardiac channelopathy (66).

Implantable Cardioverter-Defibrillators (ICD)

Current guidelines recommend ICD therapy in LQTS patients who are survivors of a cardiac arrest or in patients with a diagnosis of LQTS who experience recurrent syncopal events while on betablocker therapy (Class I). Primary prevention ICD therapy usually is not indicated in asymptomatic patients, but it could be considered in those patients who are deemed to be at very high risk, such as asymptomatic patients a resting QTc $>500$ ms while receiving beta-blockers (Class IIb) (42).

In asymptomatic patients, the protective benefit of an ICD should be balanced against the risk of device-related complications and the influence of age and gender should be considered. For example, for a male with LQTS who has remained asymptomatic by the age of 25 years, the risk of ever developing an arrhythmia is very small even in the absence of therapy. The same is not true for females, because the cumulative risk curve never appears to reach a plateau.

In patients with malignant forms of LQTS such as Jervell and Lange-Nielsen syndrome and Timothy syndrome, betablockers provides incomplete protection against life-threatening ventricular arrhythmias and combination therapy including betablockers, LSCD and ICD implantation should be strongly considered.

Acquired Long QT syndrome

Acquired LQTS is far more prevalent than congenital LQTS, and it may be the result of QT-prolonging drugs, electrolyte abnormalities (such as hypokalemia or hypomagnesemia) or bradycardia.

Several drugs can induce QT prolongation and TdP, including many in common use, such as antidepressants, antipsychotics, opiates, antiarrhythmics,

This article is protected by copyright. All rights reserved. 
antibiotics, antihistamines and prokinetics (Table 3) (42). An updated list of them can be found at www.credibledrugs.org.

Most QT-prolonging drugs block the rapid component of the cardiac-delayed rectifier current (IKr, encoded by the $\mathrm{KCNH} 2$ gene) $(67,68)$, although some drugs can also increase the late sodium current (69). Risk factors for drug-induced QT prolongation and TdP include characteristics of the drug (propensity for blockade of the delayed potassium rectifier current IKr); transient factors such as bradycardia, frequent ventricular ectopy and hypokalemia/hypomagnesemia; and patient factors such as age, female gender (especially between puberty and menopause), cardiac comorbidities, impaired repolarization reserve (the redundancy in the repolarizing currents in cardiac cells) or baseline QT prolongation which can be due to genetic or acquired conditions (70).

A particularly challenging group of medications are those used for the management of psychiatric conditions, as many psychotropic medications have been associated with QT prolongation in case reports (70). Among antidepressant medications, tricyclic antidepressants and citalopram cause more QT prolongation than other selective serotonin reuptake inhibitors (SSRI) and should be avoided as first-line therapy in patients with cardiac disease or known risk factors for QT prolongation. Escitalopram appears to prolong the QT interval to a lesser extent; fuoxetine, fluvoxamine and sertraline have similar low risk for QT prolongation; and paroxetine appears to have the lowest risk (71). However, interpretation of these studies have limitations and data about the relative safety of one SSRI over another should be taken with caution. Nearly all antipsychotics have been documented to cause QT prolongation, but typical agents carry a higher risk than atypicals. Of the typical antipsychotic medications, thioridazine causes the greatest QT prolongation. Among the atypicals agents, the greatest risk appears to be related to ziprasidone and possibly iloperidone, with aripiprazole conferring the lowest risk (71). Opioids have also been associated with QT prolongation. Methadone is a potent blocker of the hERG potassium channel and can cause QT prolongation in up to $37 \%$ of cases $(72,73)$. Buprenorphine and oxycodone can also block the hERG channel but with a much lesser potency.

There is evidence of a genetic predisposition in some subjects with acquired LQTS and genetic testing in the context of drug-induced LQTS requires individualized consideration. Up to one third of patients with acquired LQTS carry mutations in one of the major LQTS-related genes, with KCNH2 being the more common (74-76). The clinical predictors of an underlying mutation include age $<40$ years, QTc $>440 \mathrm{~ms}$ in the absence of triggers and a history of cardiac events, and it has been suggested that patients with at least 2 of these predictors are the most likely to benefit from genetic screening (74).

Management of drug-induced TdP requires discontinuation of the offending agent, administration of intravenous magnesium sulfate (1-2 grams) and repletion of potassium to maintain serum levels between 4.5 and $5.0 \mathrm{mEq} / \mathrm{L}$ (42). In case of recurrent ventricular arrhythmias despite potassium repletion and magnesium

This article is protected by copyright. All rights reserved. 
supplementation, temporary transvenous pacing or isoproterenol infusion can be used to increase heart rate and shorten the QT interval.

\section{Conclusions}

Knowledge and well-designed strategies for diagnosis and treatment of Long QT syndrome have significantly evolved in the last decade. Genetic characterization and identification of patients at increased risk of malignant ventricular arrhythmias are some of the major advances in the last few years. This article provides a brief summary of the most relevant aspects of this condition.

\section{Reference}

1. Barsheshet A, Dotsenko O, Goldenberg I. Genotype-specific risk stratification and management of patients with long QT syndrome. Ann Noninvasive Electrocardiol. 2013 Nov;18(6):499-509.

2. Schwartz PJ, Periti M, Malliani A. The long Q-T syndrome. Am Heart J 1975;89: 378-90.

3. Havakuk O, Viskin S. A Tale of 2 Diseases: The History of Long-QT Syndrome and Brugada Syndrome. J Am Coll Cardiol. 2016 Jan 5;67(1):100-8.

4. Curran ME, Splawski I, Timothy KW, Vincent GM, Green ED, Keating MT. A molecular basis for cardiac arrhythmia: HERG mutations cause long QT syndrome. Cell. 1995 Mar 10;80(5):795-803.

5. Wang Q, Shen J, Splawski I, Atkinson D, Li Z, Robinson JL, Moss AJ, Towbin JA, Keating MT. SCN5A mutations associated with an inherited cardiac arrhythmia, long QT syndrome. Cell. 1995 Mar 10;80(5):805-11.

6. Schwartz PJ, Crotti L, Insolia R. Long-QT syndrome: from genetics to management. Circ Arrhythm Electrophysiol. 2012 Aug 1;5(4):868-77. Review. Erratum in: Circ Arrhythm Electrophysiol. 2012 Dec;5(6):e119-20.

7. Schwartz PJ. Idiopathic long QT syndrome: progress and questions. Am Heart J. 1985 Feb;109(2):399-411.

8. Schwartz PJ, Stramba-Badiale M, Crotti L, Pedrazzini M, Besana A, Bosi G, Gabbarini F, Goulene K, Insolia R, Mannarino S, Mosca F, Nespoli L, Rimini A, Rosati E, Salice P, Spazzolini C. Prevalence of the congenital long-QT syndrome. Circulation. 2009 Nov 3;120(18):1761-7.

9. Bohnen MS, Peng G, Robey SH, Terrenoire C, Iyer V, Sampson KJ, Kass RS. Molecular Pathophysiology of Congenital Long QT Syndrome. Physiol Rev. 2017 Jan;97(1):89-134.

This article is protected by copyright. All rights reserved. 
10. Splawski I, Shen J, Timothy KW, Lehmann MH, Priori S, Robinson JL, Moss AJ, Schwartz PJ, Towbin JA, Vincent GM, Keating MT. Spectrum of mutations in long-QT syndrome genes. KVLQT1, HERG, SCN5A, KCNE1, and KCNE2. Circulation. 2000 Sep 5;102(10):1178-85.

11. Chen L, Marquardt ML, Tester DJ, Sampson KJ, Ackerman MJ, Kass RS. Mutation of an A-kinase-anchoring protein causes long-QT syndrome. Proc Natl Acad Sci U S A. 2007 Dec 26;104(52):20990-5.

12. Plaster NM, Tawil R, Tristani-Firouzi M, Canún S, Bendahhou S, Tsunoda A, Donaldson MR, Iannaccone ST, Brunt E, Barohn R, Clark J, Deymeer F, George AL Jr, Fish FA, Hahn A, Nitu A, Ozdemir C, Serdaroglu P, Subramony SH, Wolfe G, Fu YH, Ptácek LJ. Mutations in Kir2.1 cause the developmental and episodic electrical phenotypes of Andersen's syndrome. Cell. 2001 May 18;105(4):511-9.

13. Yang Y, Yang Y, Liang B, Liu J, Li J, Grunnet M, Olesen SP, Rasmussen HB, Ellinor PT, Gao L, Lin X, Li L, Wang L, Xiao J, Liu Y, Liu Y, Zhang S, Liang D, Peng L, Jespersen T, Chen YH. Identification of a Kir3.4 mutation in congenital long QT syndrome. Am J Hum Genet. 2010 Jun 11;86(6):872-80.

14. Vatta M, Ackerman MJ, Ye B, Makielski JC, Ughanze EE, Taylor EW, Tester DJ, Balijepalli RC, Foell JD, Li Z, Kamp TJ, Towbin JA. Mutant caveolin-3 induces persistent late sodium current and is associated with long-QT syndrome. Circulation. 2006 Nov 14;114(20):2104-12.

15. Medeiros-Domingo A, Kaku T, Tester DJ, Iturralde-Torres P, Itty A, Ye B, Valdivia C, Ueda K, Canizales-Quinteros S, Tusié-Luna MT, Makielski JC, Ackerman MJ. SCN4B-encoded sodium channel beta4 subunit in congenital long-QT syndrome. Circulation. 2007 Jul 10;116(2):134-42.

16. Ueda K, Valdivia C, Medeiros-Domingo A, Tester DJ, Vatta M, Farrugia G, Ackerman MJ, Makielski JC. Syntrophin mutation associated with long QT syndrome through activation of the nNOS-SCN5A macromolecular complex. Proc Natl Acad Sci U S A. 2008 Jul 8;105(27):9355-60.

17. Splawski I, Timothy KW, Decher N, Kumar P, Sachse FB, Beggs AH, Sanguinetti MC, Keating MT. Severe arrhythmia disorder caused by cardiac Ltype calcium channel mutations. Proc Natl Acad Sci U S A. 2005 Jun 7;102(23):8089-96; discussion 8086-8.

18. Crotti L, Spazzolini C, Tester DJ, Ghidoni A, Baruteau AE, Beckmann BM, Behr ER, Bennett JS, Bezzina CR, Bhuiyan ZA, Celiker A, Cerrone M, Dagradi F, De Ferrari GM, Etheridge SP, Fatah M, Garcia-Pavia P, Al-Ghamdi S, Hamilton RM, Al-Hassnan ZN, Horie M, Jimenez-Jaimez J, Kanter RJ, Kaski JP, Kotta MC, Lahrouchi N, Makita N, Norrish G, Odland HH, Ohno S, Papagiannis J, Parati G, Sekarski N, Tveten K, Vatta M, Webster G, Wilde

This article is protected by copyright. All rights reserved. 
AAM, Wojciak J, George AL, Ackerman MJ, Schwartz PJ. Calmodulin mutations and life-threatening cardiac arrhythmias: insights from the International Calmodulinopathy Registry. Eur Heart J. 2019 Jun 6.

19. Mohler PJ, Splawski I, Napolitano C, Bottelli G, Sharpe L, Timothy K, Priori SG, Keating MT, Bennett V. A cardiac arrhythmia syndrome caused by loss of ankyrin-B function. Proc Natl Acad Sci U S A. 2004 Jun 15;101(24):9137-42.

20. Huang X, Kim TY, Koren G, Choi BR, Qu Z. Spontaneous initiation of premature ventricular complexes and arrhythmias in type 2 long QT syndrome. Am J Physiol Heart Circ Physiol. 2016 Dec 1;311(6):H1470-H1484.

21. Vijayakumar R, Silva JNA, Desouza KA, Abraham RL, Strom M, Sacher F, Van Hare GF, Haïssaguerre M, Roden DM, Rudy Y. Electrophysiologic substrate in congenital Long QT syndrome: noninvasive mapping with electrocardiographic imaging (ECGI). Circulation. 2014 Nov 25;130(22):19361943.

22. Antzelevitch C, Shimizu W. Cellular mechanisms underlying the long QT syndrome. Curr Opin Cardiol. 2002 Jan;17(1):43-51.

23. Yan GX, Antzelevitch C. Cellular basis for the normal $T$ wave and the electrocardiographic manifestations of the long-QT syndrome. Circulation. 1998 Nov 3;98(18):1928-36.

24. Viskin S, Alla SR, Barron HV, Heller K, Saxon L, Kitzis I, Hare GF, Wong MJ, Lesh MD, Scheinman MM. Mode of onset of torsade de pointes in congenital long QT syndrome. J Am Coll Cardiol. 1996 Nov 1;28(5):1262-8.

25. Tan HL, Bardai A, Shimizu W, Moss AJ, Schulze-Bahr E, Noda T, Wilde AA. Genotype-specific onset of arrhythmias in congenital long-QT syndrome: possible therapy implications. Circulation. 2006 Nov 14;114(20):2096-103.

26. Schwartz PJ, Priori SG, Spazzolini C, Moss AJ, Vincent GM, Napolitano C, Denjoy I, Guicheney P, Breithardt G, Keating MT, Towbin JA, Beggs AH, Brink P, Wilde AA, Toivonen L, Zareba W, Robinson JL, Timothy KW, Corfield V, Wattanasirichaigoon D, Corbett C, Haverkamp W, Schulze-Bahr E, Lehmann MH, Schwartz K, Coumel P, Bloise R. Genotype-phenotype correlation in the long-QT syndrome: gene-specific triggers for life-threatening arrhythmias. Circulation. 2001 Jan 2;103(1):89-95.

27. Priori SG, Schwartz PJ, Napolitano C, Bloise R, Ronchetti E, Grillo M, Vicentini A, Spazzolini C, Nastoli J, Bottelli G, Folli R, Cappelletti D. Risk stratification in the long-QT syndrome. N Engl J Med. 2003 May 8;348(19):1866-74.

28. Vink AS, Neumann B, Lieve KVV, Sinner MF, Hofman N, El Kadi S, Schoenmaker MHA, Slaghekke HMJ, de Jong JSSG, Clur SB, Blom NA, Kääb

This article is protected by copyright. All rights reserved. 
S, Wilde AAM, Postema PG. Determination and Interpretation of the QT Interval. Circulation. 2018 Nov 20;138(21):2345-2358.

29. Schwartz PJ, Malliani A. Electrical alternation of the T-wave: clinical and experimental evidence of its relationship with the sympathetic nervous system and with the long Q-T syndrome. Am Heart J. 1975 Jan;89(1):45-50.

30. Vyas H, Hejlik J, Ackerman MJ. Epinephrine QT stress testing in the evaluation of congenital long-QT syndrome: diagnostic accuracy of the paradoxical QT response. Circulation. 2006 Mar 21;113(11):1385-92.

31. Horner JM, Horner MM, Ackerman MJ. The diagnostic utility of recovery phase QTc during treadmill exercise stress testing in the evaluation of long QT syndrome. Heart Rhythm. 2011 Nov;8(11):1698-704.

32. Viskin S, Postema PG, Bhuiyan ZA, Rosso R, Kalman JM, Vohra JK, Guevara-Valdivia ME, Marquez MF, Kogan E, Belhassen B, Glikson M, Strasberg B, Antzelevitch C, Wilde AA. The response of the QT interval to the brief tachycardia provoked by standing: a bedside test for diagnosing long QT syndrome. J Am Coll Cardiol. 2010 May 4;55(18):1955-61.

33. Chorin E, Havakuk O, Adler A, Steinvil A, Rozovski U, van der Werf C, Postema PG, Topaz G, Wilde AA, Viskin S, Rosso R. Diagnostic value of Twave morphology changes during "QT stretching" in patients with long QT syndrome. Heart Rhythm. 2015 Nov;12(11):2263-71.

34. Adler A, van der Werf C, Postema PG, Rosso R, Bhuiyan ZA, Kalman JM, Vohra JK, Guevara-Valdivia ME, Marquez MF, Halkin A, Benhorin J, Antzelevitch C, Wilde AA, Viskin S. The phenomenon of "QT stunning": the abnormal QT prolongation provoked by standing persists even as the heart rate returns to normal in patients with long QT syndrome. Heart Rhythm. 2012 Jun;9(6):901-8.

35. Tester DJ, Will ML, Haglund CM, Ackerman MJ. Effect of clinical phenotype on yield of long QT syndrome genetic testing. J Am Coll Cardiol. 2006 Feb 21;47(4):764-8.

36. Schwartz PJ, Spazzolini C, Crotti L, Bathen J, Amlie JP, Timothy K, Shkolnikova M, Berul CI, Bitner-Glindzicz M, Toivonen L, Horie M, SchulzeBahr E, Denjoy I. The Jervell and Lange-Nielsen syndrome: natural history, molecular basis, and clinical outcome. Circulation. 2006 Feb 14;113(6):783-90.

37. Splawski I, Timothy KW, Sharpe LM, Decher N, Kumar P, Bloise R, Napolitano C, Schwartz PJ, Joseph RM, Condouris K, Tager-Flusberg H, Priori SG, Sanguinetti MC, Keating MT. Ca(V)1.2 calcium channel dysfunction causes a multisystem disorder including arrhythmia and autism. Cell. 2004 Oct 1;119(1):19-31.

This article is protected by copyright. All rights reserved. 
38. Moss AJ, Shimizu W, Wilde AA, Towbin JA, Zareba W, Robinson JL, Qi M, Vincent GM, Ackerman MJ, Kaufman ES, Hofman N, Seth R, Kamakura S, Miyamoto Y, Goldenberg I, Andrews ML, McNitt S. Clinical aspects of type-1 long-QT syndrome by location, coding type, and biophysical function of mutations involving the KCNQ1 gene. Circulation. 2007 May 15;115(19):2481-9.

39. Moss AJ, Zareba W, Kaufman ES, Gartman E, Peterson DR, Benhorin J, Towbin JA, Keating MT, Priori SG, Schwartz PJ, Vincent GM, Robinson JL, Andrews ML, Feng C, Hall WJ, Medina A, Zhang L, Wang Z. Increased risk of arrhythmic events in long-QT syndrome with mutations in the pore region of the human ether-a-go-go-related gene potassium channel. Circulation. 2002 Feb 19;105(7):794-9.

40. Priori SG, Napolitano C, Schwartz PJ, Grillo M, Bloise R, Ronchetti E, Moncalvo C, Tulipani C, Veia A, Bottelli G, Nastoli J. Association of long QT syndrome loci and cardiac events among patients treated with beta-blockers. JAMA. 2004 Sep 15;292(11):1341-4.

41. Spazzolini C, Mullally J, Moss AJ, Schwartz PJ, McNitt S, Ouellet G, Fugate T, Goldenberg I, Jons C, Zareba W, Robinson JL, Ackerman MJ, Benhorin J, Crotti L, Kaufman ES, Locati EH, Qi M, Napolitano C, Priori SG, Towbin JA, Vincent GM. Clinical implications for patients with long QT syndrome who experience a cardiac event during infancy. J Am Coll Cardiol. 2009 Aug 25;54(9):832-7.

42. Al-Khatib SM, Stevenson WG, Ackerman MJ, Bryant WJ, Callans DJ, Curtis AB, Deal BJ, Dickfeld T, Field ME, Fonarow GC, Gillis AM, Granger CB, Hammill SC, Hlatky MA, Joglar JA, Kay GN, Matlock DD, Myerburg RJ, Page RL. 2017 AHA/ACC/HRS guideline for management of patients with ventricular arrhythmias and the prevention of sudden cardiac death: A Report of the American College of Cardiology/American Heart Association Task Force on Clinical Practice Guidelines and the Heart Rhythm Society. Heart Rhythm. 2018 Oct;15(10):e73-e189.

43. Goldenberg I, Moss AJ, Peterson DR, McNitt S, Zareba W, Andrews ML, Robinson JL, Locati EH, Ackerman MJ, Benhorin J, Kaufman ES, Napolitano C, Priori SG, Qi M, Schwartz PJ, Towbin JA, Vincent GM, Zhang L. Risk factors for aborted cardiac arrest and sudden cardiac death in children with the congenital long-QT syndrome. Circulation. 2008 Apr 29; 117(17):2184-91.

44. Chockalingam P, Crotti L, Girardengo G, Johnson JN, Harris KM, van der Heijden JF, Hauer RN, Beckmann BM, Spazzolini C, Rordorf R, Rydberg A, Clur SA, Fischer M, van den Heuvel F, Kääb S, Blom NA, Ackerman MJ, Schwartz PJ, Wilde AA. Not all beta-blockers are equal in the management of long QT syndrome types 1 and 2: higher recurrence of events under metoprolol. J Am Coll Cardiol. 2012 Nov 13;60(20):2092-9.

This article is protected by copyright. All rights reserved. 
45. Abu-Zeitone A, Peterson DR, Polonsky B, McNitt S, Moss AJ. Efficacy of different beta-blockers in the treatment of long QT syndrome. J Am Coll Cardiol. 2014 Sep 30;64(13):1352-8.

46. Mazzanti A, Maragna R, Vacanti G, Monteforte N, Bloise R, Marino M, Braghieri L, Gambelli P, Memmi M, Pagan E, Morini M, Malovini A, Ortiz M, Sacilotto L, Bellazzi R, Monserrat L, Napolitano C, Bagnardi V, Priori SG. Interplay Between Genetic Substrate, QTc Duration, and Arrhythmia Risk in Patients With Long QT Syndrome. J Am Coll Cardiol. 2018 Apr 17;71(15):1663-1671.

47. Schwartz PJ. Pharmacological and non-pharmacological management of the congenital long QT syndrome: the rationale. Pharmacol Ther. 2011 Jul; 131(1):171-7.

48. Goldenberg I, Bradley J, Moss A, McNitt S, Polonsky S, Robinson JL, Andrews M, Zareba W; International LQTS Registry Investigators. Betablocker efficacy in high-risk patients with the congenital long-QT syndrome types 1 and 2: implications for patient management. J Cardiovasc Electrophysiol. 2010 Aug 1; 21(8):893-901.

49. Moss AJ, Zareba W, Hall WJ, Schwartz PJ, Crampton RS, Benhorin J, Vincent GM, Locati EH, Priori SG, Napolitano C, Medina A, Zhang L, Robinson JL, Timothy K, Towbin JA, Andrews ML. Effectiveness and limitations of betablocker therapy in congenital long-QT syndrome. Circulation. 2000 Feb 15; 101(6):616-23.

50. Vincent GM, Schwartz PJ, Denjoy I, Swan H, Bithell C, Spazzolini C, Crotti L, Piippo K, Lupoglazoff JM, Villain E, Priori SG, Napolitano C, Zhang L. High efficacy of beta-blockers in long-QT syndrome type 1: contribution of noncompliance and QT-prolonging drugs to the occurrence of beta-blocker treatment "failures". Circulation. 2009 Jan 20;119(2):215-21.

51. Bos JM, Bos KM, Johnson JN, Moir C, Ackerman MJ. Left cardiac sympathetic denervation in long QT syndrome: analysis of therapeutic nonresponders. Circ Arrhythm Electrophysiol. 2013 Aug;6(4):705-11.

52. Schwartz PJ, Priori SG, Cerrone M, Spazzolini C, Odero A, Napolitano C, Bloise R, De Ferrari GM, Klersy C, Moss AJ, Zareba W, Robinson JL, Hall WJ, Brink PA, Toivonen L, Epstein AE, Li C, Hu D. Left cardiac sympathetic denervation in the management of high-risk patients affected by the long-QT syndrome. Circulation. 2004 Apr 20;109(15):1826-33.

53. Etheridge SP, Compton SJ, Tristani-Firouzi M, Mason JW. A new oral therapy for long QT syndrome: long-term oral potassium improves repolarization in patients with HERG mutations. J Am Coll Cardiol. 2003 Nov 19;42(10):177782.

This article is protected by copyright. All rights reserved. 
54. Priori SG, Napolitano C, Cantù F, Brown AM, Schwartz PJ. Differential response to $\mathrm{Na}+$ channel blockade, beta-adrenergic stimulation, and rapid pacing in a cellular model mimicking the SCN5A and HERG defects present in the long-QT syndrome. Circ Res. 1996 Jun;78(6):1009-15.

55. Shimizu W, Antzelevitch C. Sodium channel block with mexiletine is effective in reducing dispersion of repolarization and preventing torsade des pointes in LQT2 and LQT3 models of the long-QT syndrome. Circulation. 1997 Sep 16;96(6):2038-47.

56. Schwartz PJ, Priori SG, Locati EH, Napolitano C, Cantù F, Towbin JA, Keating MT, Hammoude H, Brown AM, Chen LS, Colatsky TJ. Long QT syndrome patients with mutations of the SCN5A and HERG genes have differential responses to $\mathrm{Na}+$ channel blockade and to increases in heart rate. Implications for gene-specific therapy. Circulation. 1995 Dec 15;92(12):33816.

57. Mazzanti A, Maragna R, Faragli A, Monteforte N, Bloise R, Memmi M, Novelli V, Baiardi P, Bagnardi V, Etheridge SP, Napolitano C, Priori SG. Gene-Specific Therapy With Mexiletine Reduces Arrhythmic Events in Patients With Long QT Syndrome Type 3. J Am Coll Cardiol. 2016 Mar 8;67(9):1053-8.

58. Ruan Y, Liu N, Bloise R, Napolitano C, Priori SG. Gating properties of SCN5A mutations and the response to mexiletine in long-QT syndrome type 3 patients. Circulation. 2007 Sep 4;116(10):1137-44.

59. Bos JM, Crotti L, Rohatgi RK, Castelletti S, Dagradi F, Schwartz PJ, Ackerman MJ. Mexiletine Shortens the QT Interval in Patients With Potassium Channel-Mediated Type 2 Long QT Syndrome. Circ Arrhythm Electrophysiol. 2019 May;12(5):e007280.

60. Chorin E, Taub R, Medina A, Flint N, Viskin S, Benhorin J. Long-term flecainide therapy in type 3 long QT syndrome. Europace. 2018 Feb 1;20(2):370-376.

61. Chorin E, Hu D, Antzelevitch C, Hochstadt A, Belardinelli L, Zeltser D, Barajas-Martinez H, Rozovski U, Rosso R, Adler A, Benhorin J, Viskin S. Ranolazine for Congenital Long-QT Syndrome Type III: Experimental and Long-Term Clinical Data. Circ Arrhythm Electrophysiol. 2016 Oct;9(10).

62. Priori SG, Wilde AA, Horie M, Cho Y, Behr ER, Berul C, Blom N, Brugada J, Chiang CE, Huikuri H, Kannankeril P, Krahn A, Leenhardt A, Moss A, Schwartz PJ, Shimizu W, Tomaselli G, Tracy C. HRS/EHRA/APHRS expert consensus statement on the diagnosis and management of patients with inherited primary arrhythmia syndromes: document endorsed by HRS, EHRA,

This article is protected by copyright. All rights reserved. 
and APHRS in May 2013 and by ACCF, AHA, PACES, and AEPC in June 2013. Heart Rhythm. 2013 Dec; 10(12):1932-63.

63. Chorin E, Hochstadt A, Granot Y, Khoury S, Schwartz AL, Margolis G, Barashi R, Viskin D, Ghantous E, Schnapper M, Mekori T, Fourey D, Guevara-Valdivia ME, Marquez MF, Zeltzer D, Rosso R, Viskin S. Grapefruit juice prolongs the QT interval of healthy volunteers and patients with long QT syndrome. Heart Rhythm. 2019 Aug;16(8):1141-1148.

64. Pelliccia A, Zipes DP, Maron BJ. Bethesda Conference \#36 and the European Society of Cardiology Consensus Recommendations revisited a comparison of U.S. and European criteria for eligibility and disqualification of competitive athletes with cardiovascular abnormalities. J Am Coll Cardiol. 2008 Dec 9; 52(24):1990-6.

65. Johnson JN, Ackerman MJ. Competitive sports participation in athletes with congenital long QT syndrome. JAMA. 2012 Aug 22;308(8):764-5.

66. Ackerman MJ, Zipes DP, Kovacs RJ, Maron BJ. Eligibility and Disqualification Recommendations for Competitive Athletes With Cardiovascular Abnormalities: Task Force 10: The Cardiac Channelopathies: A Scientific Statement From the American Heart Association and American College of Cardiology. J Am Coll Cardiol. 2015 Dec 1;66(21):2424-2428.

67. Digby G, Pérez Riera AR, Barbosa Barros R, Simpson CS, Redfearn DP, Methot M, Femenia F, Baranchuk A. Acquired Long QT Interval: A Case Series of Multifactorial QT Prolongation. Clin Cardiol 2011;(34) 9: 577-582

68. El-Sherif N, Turitto G. Electrolyte disorders and arrhythmogenesis. Cardiol J. 2011;18(3):233-45.

69. Yang T, Chun YW, Stroud DM, Mosley JD, Knollmann BC, Hong C, Roden DM. Screening for acute IKr block is insufficient to detect torsades de pointes liability: role of late sodium current. Circulation. 2014 Jul 15;130(3):224-34.

70. Beach SR, Celano CM, Sugrue AM, Adams C, Ackerman MJ, Noseworthy PA, Huffman JC. QT Prolongation, Torsades de Pointes, and Psychotropic Medications: A 5-Year Update. Psychosomatics. 2018 Mar - Apr;59(2):105122.

71. Funk KA, Bostwick JR. A comparison of the risk of QT prolongation among SSRIs. Ann Pharmacother. 2013 Oct;47(10):1330-41.

72. Zerdazi EH, Vorspan F, Marees AT, Naccache F, Lepine JP, Laplanche JL, Prince N, Marie-Claire C, Bellivier F, Mouly S, Bloch V. QT length during methadone maintenance treatment: gene $\times$ dose interaction. Fundam Clin Pharmacol. 2019 Feb;33(1):96-106.

This article is protected by copyright. All rights reserved. 
73. Digby GC; Fong C, Methot M; Simpson CS; Redfearn DP; Baranchuk A. Acquired QT Interval Prolongation \& Methadone: The Risk of Pharmacological Interaction. J Clinic Experiment Cardiol 2011; 2:116

74. Itoh H, Crotti L, Aiba T, Spazzolini C, Denjoy I, Fressart V, Hayashi K, Nakajima T, Ohno S, Makiyama T, Wu J, Hasegawa K, Mastantuono E, Dagradi F, Pedrazzini M, Yamagishi M, Berthet M, Murakami Y, Shimizu W, Guicheney P, Schwartz PJ, Horie M. The genetics underlying acquired long QT syndrome: impact for genetic screening. Eur Heart J. 2016 May 7;37(18):145664.

75. Yang P, Kanki H, Drolet B, Yang T, Wei J, Viswanathan PC, Hohnloser SH, Shimizu W, Schwartz PJ, Stanton M, Murray KT, Norris K, George AL Jr, Roden DM. Allelic variants in long-QT disease genes in patients with drugassociated torsades de pointes. Circulation. 2002 Apr 23;105(16):1943-8.

76. Lehtonen A, Fodstad H, Laitinen-Forsblom P, Toivonen L, Kontula K, Swan H. Further evidence of inherited long QT syndrome gene mutations in antiarrhythmic drug-associated torsades de pointes. Heart Rhythm. 2007 May;4(5):603-7.

77. Pérez-Riera AR, Barbosa-Barros R, Daminello Raimundo R, da Costa de Rezende Barbosa MP, Esposito Sorpreso IC, de Abreu LC. The congenital long QT syndrome Type 3: An update. Indian Pacing Electrophysiol J. 2018 JanFeb;18(1):25-35

\section{Figures}

Figure 1. 12-lead ECG of main subtypes of LQTS. A. LQT1: Note typical wide-based T-waves with large amplitude. B. LQT2: Note remarkable T-U wave morphology. $\mathbf{C}$. LQT3 (newborn baby). Note ST-segment prolongation and delayed appearance of Twave. Courtesy of Dr. Andres Perez-Riera

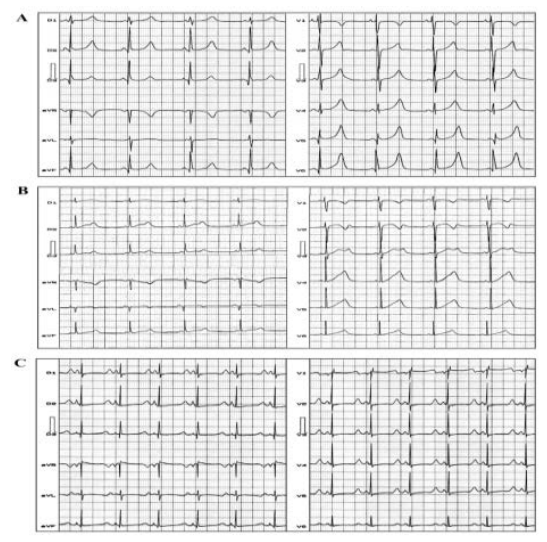

This article is protected by copyright. All rights reserved. 
Figure 2. Ventricular arrhythmias in the context of congenital and acquired LQTS. A. T-Wave Alternans in a 6 year-old caucasian female diagnosed with congenital LQT3, note QTc interval of 670 ms. Reproduced with permission from reference \#77. B. Torsades de Pointes due to prolonged QT interval in the context of acquired thirddegree AV block.
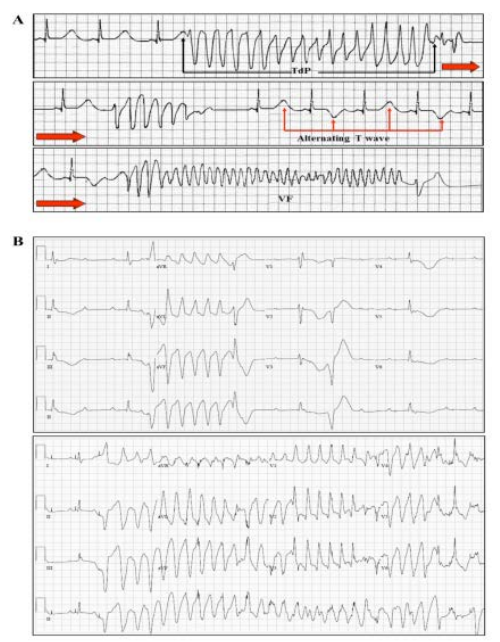

Figure 3. Management of congenital LQTS.

ICD: Implantable cardioverter-defibrillator; LCSD: Left cardiac sympathetic denervation.

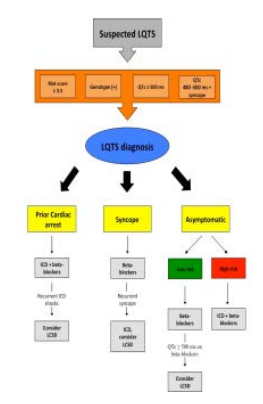

This article is protected by copyright. All rights reserved. 


\section{Tables}

Table 1. Subtypes of congenital long QT syndromes.

\begin{tabular}{|c|c|c|c|c|c|c|}
\hline $\begin{array}{l}\text { LQT } \\
\text { subtype }\end{array}$ & Gene & Locus & Protein mutated & $\begin{array}{l}\text { Current } \\
\text { affected }\end{array}$ & $\begin{array}{l}\text { Inheritance } \\
\text { pattern }\end{array}$ & Frequency \\
\hline LQT1 & KCNQ1 & 11p15.5 & $\begin{array}{l}\text { Alfa-subunit for } \mathrm{K}^{+} \\
\text {channel [Kv7.1] }\end{array}$ & $\downarrow \mathrm{I}_{\mathrm{Ks}}$ & $\begin{array}{l}\text { Autosomal } \\
\text { dominant/recessive }\end{array}$ & $30-35 \%$ \\
\hline LQT2 & KCNH2 & 7q35-46 & $\begin{array}{l}\text { Alfa-subunit for } \mathrm{K}^{+} \\
\text {channel [Kv11.1] }\end{array}$ & $\downarrow \mathrm{I}_{\mathrm{Kr}}$ & Autosomal dominant & $25-30 \%$ \\
\hline LQT3 & SCN5A & 3p21-p24 & $\begin{array}{l}\mathrm{Na}^{+} \text {channel } \\
{\left[\mathrm{Na}_{\mathrm{v}} 1.5\right]}\end{array}$ & $\uparrow \mathrm{I}_{\mathrm{Na}}$ & Autosomal dominant & $5-10 \%$ \\
\hline LQT4 & ANK2 & $4 q 25-q 27$ & Ankyrin-B & $\begin{array}{l}\text { Multichannel } \\
\text { interactions }\end{array}$ & Autosomal dominant & $<1 \%$ \\
\hline LQT5 & KCNE1 & 21q22.1 & $\begin{array}{l}\text { Beta-subunit of } \mathrm{K}^{+} \\
\text {channel [MinK] }\end{array}$ & $\downarrow \mathrm{I}_{\mathrm{Ks}}$ & Autosomal dominant & Very rare \\
\hline LQT6 & KCNE2 & 21q22.1 & $\begin{array}{l}\text { Beta-subunit of } \\
\text { channel [MiRP1] }\end{array}$ & $\downarrow \mathrm{I}_{\mathrm{Kr}}$ & Autosomal dominant & $<1 \%$ \\
\hline LQT7 & KCNJ2 & $17 q 23$ & $\begin{array}{ll}\begin{array}{l}\text { Alfa-subunit } \\
\text { channel }\left[K_{\mathrm{ir}} 2.1\right]\end{array} & \mathrm{K}^{+}\end{array}$ & $\downarrow \mathrm{I}_{\mathrm{K} 1}$ & Autosomal dominant & $<1 \%$ \\
\hline LQT8 & CACNA1C & 12p13.3 & $\begin{array}{l}\text { L-type } \mathrm{Ca}^{2+} \\
{\left[\mathrm{Ca}_{\mathrm{v}} 1.2\right]}\end{array}$ & $\uparrow \mathrm{I}_{\mathrm{CaL}}$ & Sporadic & Very rare \\
\hline LQT9 & CAV3 & $3 p 25$ & $\begin{array}{l}\text { Scaffolding protein } \\
\text { [Caveolin 3] }\end{array}$ & $\uparrow \mathrm{I}_{\mathrm{Na}}$ & Autosomal dominant & $<1 \%$ \\
\hline LQT10 & SCN4B & $11 \mathrm{q} 23.3$ & $\begin{array}{lr}\text { Beta-subunit } & \text { of } \\
\text { SCN5A } & \text { channel } \\
{\left[\mathrm{Na}_{\mathrm{v}} 1.5 \beta 4\right]} & \end{array}$ & $\uparrow \mathrm{I}_{\mathrm{Na}}$ & Autosomal dominant & $<1 \%$ \\
\hline LQT11 & AKAP9 & 7q21-q22 & $\begin{array}{l}\text { A-kinase anchor } \\
\text { protein } 9 \text { [Yotiao] }\end{array}$ & $\downarrow \mathrm{I}_{\mathrm{Ks}}$ & Autosomal dominant & $<1 \%$ \\
\hline LQT12 & SNTA1 & $20 \mathrm{q} 11.2$ & $\begin{array}{l}\text { Alpha-1-syntrophin } \\
\text { protein }\end{array}$ & $\uparrow \mathrm{I}_{\mathrm{Na}}$ & Autosomal dominant & $<1 \%$ \\
\hline
\end{tabular}

This article is protected by copyright. All rights reserved. 


\begin{tabular}{|c|c|c|c|c|c|c|}
\hline LQT13 & KCNJ5 & $11 \mathrm{q} 24$ & $\begin{array}{l}\text { Alfa-subunit } \\
\text { channel } \\
\text { [GIRK4] }\end{array}$ & $\begin{array}{r}\mathrm{K}^{+} \\
\mathrm{K}_{\mathrm{ir}} 3.4\end{array}$ & $\downarrow \mathrm{I}_{\mathrm{KACh}}$ & Autosomal dominant \\
\hline LQT14 & CALM1 & $\begin{array}{l}\text { 14q24- } \\
\text { q31 }\end{array}$ & Calmodulin 1 & & Increase $\mathrm{I}_{\mathrm{CaL}}$ & Sporadic \\
\hline LQT15 & CALM2 & $2 \mathrm{p} 21$ & Calmodulin 2 & & Increase $\mathrm{I}_{\mathrm{CaL}}$ & Sporadic \\
\hline LQT16 & CALM3 & $19 q 13$ & Calmodulin 3 & & $\begin{array}{l}\text { Likely increase } \\
\mathrm{I}_{\mathrm{CaL}}\end{array}$ & Sporadic \\
\hline
\end{tabular}

Table 2. Diagnostic score for LQTS

Points

Electrocardiographic findings ${ }^{+}$

A QTc ${ }^{*}$ interval

$\geq 480 \mathrm{~ms}$

3

$460-479 \mathrm{~ms}$

2

$450-459$ ms (men)

1

B QTc $\geq 480 \mathrm{~ms}$ during $2^{\text {nd }}-4^{\text {th }}$ minute of recovery from exercise stress test

1

C Documented torsade de pointes ${ }^{\ddagger}$

2

D T-wave alternans

1

This article is protected by copyright. All rights reserved. 
Clinical history

A Syncope $e^{\ddagger}$

With stress

Family history

A Relatives with clinically definitive LQTS ${ }^{\S}$

Total score indicates probability of LQTS: $\leq 1$ point (low), $2-3$ points (intermediate), $\geq 3.5$ points (high).

*QTc calculated using Bazett formula.

${ }^{+}$In the absence of medication, electrolyte abnormalities, or disorders known to influence these electrocardiographic parameters.

${ }^{\ddagger}$ Mutually exclusive.

$\S_{\text {S }}$ ame family member cannot be counted twice. 
Table 3. Examples of commonly used QT-prolonging medications

\begin{tabular}{|c|c|c|c|c|c|}
\hline Antiarrhythmics & Antidepressants & Antipsychotics & Antibiotics & Antihistamines & Others \\
\hline Disopyramide & Amitriptyline & Haloperidol & Erytromycin & Loratadine & Methadone \\
\hline Procainamide & Desipramine & Phenothiazines & Pentamidine & Astemizole & Probucol \\
\hline Quinidine & Imipramine & Citalopram & Azithromycin & Diphenhydramine & Droperidol \\
\hline Dofetilide & Doxepin & Tricyclic & Chloroquine & Hidroxyzine & Ondasentron \\
\hline Dronedarone & Fluoxetine & & Ciprofloxacin & & \\
\hline Ibutilide & Sertraline & & Fluconazole & & \\
\hline Sotalol & Venlafaxine & & Levofloxacin & & \\
\hline \multirow[t]{4}{*}{ Amiodarone } & & & Moxifloxacin & & \\
\hline & & & Clarithromycin & & \\
\hline & & & Itraconazole & & \\
\hline & & & Ketoconazole & & \\
\hline
\end{tabular}

This article is protected by copyright. All rights reserved. 